\title{
FINANCIAL ASPECTS OF PEPPER (Capsicum annuum L) PRODUCTION ON FAMILY FARMS IN SERBIA
}

\author{
Mladen Petrović, Bojan Savić2, Vojin Cvijanović3 \\ *Corresponding authorE-mail: mpetrovic@ipn.bg.ac.rs
}

\begin{abstract}
A R T I C LE IN F O
A B S T R A C T

Original Article

Received: 01 September 2021

Accepted: 09 December 2021

doi:10.5937/ekoPolj2104015P

UDC 338.314:635.649(497.11)

Keywords:

gross margin, variable costs, family farms, sustainability, competitiveness.

JEL: M41, O13, Q12

In the structure of agricultural production in the Republic of Serbia, crop production is dominant, while the share of vegetables in crop production is small (about 3.5\%). According to the research conducted by the Institute for the Application of Science in Agriculture during 20152019 , one of the most profitable vegetable production is pepper production. The aim of this paper is to investigate the financial aspects of pepper (Capsicum annuum L) production as one of the most common vegetable crop in the Republic of Serbia, and to assess its economic viability. The following methods were used: survey, comparison, desk research, gross margin calculation and sensitivity analysis. Sensitivity analysis showed that in addition to the yield, the price also has a great influence on the amount of the gross margin. The price risk would be reduced if there were "contracted agricultural production", which would improve the profitability and sustainability of pepper production.
\end{abstract}

(C) 2021 EA. All rights reserved.

\section{Introduction}

Agriculture is one of the most important economic activities in the Republic of Serbia, which is confirmed by the fact that the share of gross domestic product (GDP) of agriculture amounts to $7.4 \%$ of the total GDP, and the share of employees in agriculture amounts to $15.6 \%$ of the total number of employees in the economy. Vegetable production in the Republic of Serbia is conducted on about 130,000 hectares, and the key carriers of agricultural production are family farms. Small farms are dominant, with an average of 5.5 hectares of land, which is significantly smaller when compared

1 Mladen Petrović, Junior Researcher, Institute for Science Application in Agriculture, Bul. despota Stefana 68b, Phone: +381605251195, E-mail: mpetrovic@ipn.bg.ac.rs, ORCID ID: (https://orcid.org/0000-0002-4390-9711)

2 Bojan Savić, Associate Professor, University of Belgrade - Faculty of Agriculture, Nemanjina 6, Beograd-Zemun, Phone: +381114413211, E-mail: bsavic@agrif.bg.ac.rs, ORCID ID: (https://orcid.org/0000- 0002-3863-9630)

3 Vojin Cvijanović, Research Associate, Institute for Science Application in Agriculture, Bul. despota Stefana 68b, Phone: +381637277981, E-mail: vcvijanovic@ipn.bg.ac.rs, ORCID ID: (https://orcid.org/0000-0002-1347-952X) 
to farms in the EU. The vegetable production is a highly intensive and profitable branch of agricultural production, so it can have a significant impact on development of agricultural sector, but this production also significantly depends on the level of overall economic development. Vegetable production requires much labor engagement. The results show that producing one ton of peppers requires about 28 hours of human labor and 3.65 machine hours (Peševski et al., 2016). Vegetable production enables intensive use of land and irrigation systems, and it is possible to change two to three types of vegetables during the year. The specificity of a large number of vegetable species enables the production of food even in unfavorable climatic conditions, with the use of indoor production systems (greenhouses, hothouses).

The subject of this paper is an analysis of pepper production, as one of the most common vegetable crops in the Republic of Serbia, and the presentation of the financial aspects of this production on Serbian farms. The aim of the research is to look at the profitability of pepper production based on the analysis of data, as well as to consider current issues important for the sustainability of production.

\section{Materials and Methods}

For the purpose of this paper, there have been analyzed the data collected by the Institute for Science Application in Agriculture (ISAA) on gross margins in pepper production on family farms where this vegetable crop is most represented and where it this production is dominant. The number of collected and analyzed data on gross margins in the period 2015-2019 is presented in Table 1.

Table 1. Collected gross margin data from the family farms producing paper in Serbia for the period 2015-2019

\begin{tabular}{|c|c|c|c|c|c|}
\hline Years & 2015 & 2016 & 2017 & 2018 & 2019 \\
\hline Numbers & 41 & 43 & 51 & 39 & 44 \\
\hline
\end{tabular}

Source: ISAA Survey

The analysis of areas and production of the pepper was made based on the official statistical data published by the Statistical Office of the Republic of Serbia, as well as on relevant domestic publications and Internet sources. Gross margin analysis was made by using the data from a survey carried out by the Institute for Science Application in Agriculture. Comparisons of individual parameters were performed between two regions, Serbia North (includes the region of Vojvodina and the Belgrade region) and Serbia South (includes the region of Southern and Eastern Serbia and the region of Sumadija and Western Serbia) in accordance with the methodology applied by the Statistical Office of the Republic of Serbia. The data on gross margins in vegetable production were obtained from the survey conducted by the Agricultural Advisory and Expert Services of the Republic of Serbia, whose work is controlled by the Institute for Science Application in Agriculture, an organization authorized for the implementation of the Annual Program for the Development of Agricultural Advisory Affairs since 
1990. Using the collected data on gross margins, the economic and financial aspects of vegetable production on selected family farms were monitored and analyzed in order to improve the profitability of farms.

\section{Results and Discussion}

The Republic of Serbia is a well-known producer of pepper, especially of industrial varieties, and in 2019 the area under pepper was at the level of about 10,000 hectares, mainly in the open field, with an average yield of about $11.7 \mathrm{t} / \mathrm{ha}$, while indoor areas were rather negligible. Outdoor production is characterized by significantly lower costs of production, compared to the production in greenhouses and hothouses (Seepersad et al., 2013). In Serbia, pepper is grown in almost all parts of the country, and the most famous varieties are Leskovac red pepper, used fresh, but also for processing into ajvar and ground-ale pepper, and Somborska babura, used for pickling and preparation of traditional dishes (Maksimović 2004). Factors such as food safety, the paradigm shift from producer-driven value chains to demand-driven value chains, the globalization of supply chains, and the intensification of quality-based competition have, among other things, led to significant changes in vegetables export value chains (Gachukia, 2016).

Table 2. Areas under pepper in the Republic of Serbia and the regions of Serbia North and Serbia South for the period 2015-2019

\begin{tabular}{|c|c|c|c|c|c|c|c|c|c|}
\hline Regions & \multicolumn{2}{|c|}{ Republic of Serbia } & \multicolumn{3}{c|}{ Serbia North } & \multicolumn{3}{c|}{ Serbia South } \\
\hline Year & $\begin{array}{c}\text { Land } \\
\text { area } \\
\text { (in ha) }\end{array}$ & $\begin{array}{c}\text { FBIN* } \\
(\%)\end{array}$ & $\begin{array}{c}\text { CBIN } \\
* * \\
(\%)\end{array}$ & $\begin{array}{c}\text { Land } \\
\text { area } \\
\text { (in ha) }\end{array}$ & $\begin{array}{c}\text { FBIN* } \\
(\%)\end{array}$ & $\begin{array}{c}\text { CBIN } \\
* * \\
(\%)\end{array}$ & $\begin{array}{c}\text { Land area } \\
\text { (in ha) }\end{array}$ & $\begin{array}{c}\text { FBIN* } \\
(\%)\end{array}$ & $\begin{array}{c}\text { CBIN } \\
* * \\
(\%)\end{array}$ \\
\hline 2015 & 14,845 & 100.00 & 100.00 & 3,471 & 100.00 & 100.00 & 11,374 & 100.00 & 100.00 \\
\hline 2016 & 16,977 & 114.36 & 114.36 & 4,229 & 121.84 & 121.84 & 12,748 & 112.08 & 112.08 \\
\hline 2017 & 17,386 & 117.12 & 102.41 & 4,371 & 125.93 & 103.36 & 13,015 & 114.43 & 102.09 \\
\hline 2018 & 12,016 & 80.94 & 69.11 & 2,014 & 58.02 & 46.08 & 10,002 & 87.94 & 76.85 \\
\hline 2019 & 10,097 & 68.02 & 84.03 & 1,323 & 38.12 & 65.69 & 8,774 & 77.14 & 87.72 \\
\hline
\end{tabular}

* Fixed base index numbers

**Chain base index numbers

Source: Authors' calculation based on data collected from the ISAA survey on selected family farms

Data on the variation of areas under pepper in the Republic of Serbia and the regions of Serbia North and Serbia South for the 2015-2019 period are shown in Table 2. Looking at the regions of Serbia North and Serbia South, almost 90\% of the total area under pepper is located in the region of Serbia South. Based on the presented data, it can be seen that the areas under pepper were largest in 2017, when they amounted to 17,386 hectares, while they were lowest in 2019, when they amounted to 10,097 hectares. The highest growth of areas, as shown by the indicator calculated by the base index, was recorded in 2016, when the areas under pepper were $14.36 \%$ higher compared to 2015. 
In the same year (2016) there was the largest increase in the area under pepper when observed by particular regions (Serbia North and Serbia South), but slightly higher growth was recorded in the region of Serbia North and it amounted to $21.84 \%$, while in the region of Serbia South it amounted to $12.08 \%$. In 2019, the area under pepper was $31.98 \%$ smaller compared to 2015 . The smallest areas under pepper were recorded in 2019 (about 7,000 hectares), which is a significant decrease of about 45\% in comparison with the one in 2017. Looking at the particular regions of Serbia North and Serbia South, it can be concluded that the situation is similar in those regions to the territory of the whole country, with a significantly higher reduction of areas under pepper in the region of Serbia North. The indicator obtained by the calculation of base indices shows a decrease in the area under pepper. In 2019 there was a decrease of $61.88 \%$ for the Serbia North region and 32.86\% for the region of Serbia South, when compared to 2015 . The obtained volume of pepper production mainly follows the areas on which pepper is grown, so lower yields were achieved in the years when smaller areas under these vegetables were exploited. The largest production was achieved in 2016, although the areas under pepper that year were somewhat smaller than in 2017. Based on the presentation, it can also be concluded that the yields of pepper, when observing the regions of Serbia North and Serbia South, are proportional to the areas where pepper is present, from which it can be concluded that the average yields in some years are similar.

Table 3. Pepper production in the Republic of Serbia, regions of Serbia North and Serbia South for the 2015-2019 period

\begin{tabular}{|c|c|c|c|c|c|c|c|c|c|}
\hline Region & \multicolumn{3}{|c|}{ Republic of Serbia } & \multicolumn{3}{c|}{ Serbia-North } & \multicolumn{3}{c|}{ Serbia-South } \\
\hline Year & Yield (t) & $\begin{array}{c}\text { FBIN } \\
(\%)\end{array}$ & $\begin{array}{c}\text { CBIN } \\
(\%)\end{array}$ & Yield (t) & $\begin{array}{c}\text { FBIN } \\
(\%)\end{array}$ & $\begin{array}{c}\text { CBIN } \\
(\%)\end{array}$ & Yield (t) & $\begin{array}{c}\text { FBIN } \\
(\%)\end{array}$ & $\begin{array}{c}\text { CBIN } \\
(\%)\end{array}$ \\
\hline 2015 & 165,195 & 100.00 & 100.00 & 44,130 & 100.00 & 100.00 & 121,065 & 100.00 & 100.00 \\
\hline 2016 & 227,645 & 137.80 & 137.80 & 61,921 & 140.31 & 140.31 & 165,724 & 136.89 & 136.89 \\
\hline 2017 & 198,583 & 120.21 & 87.23 & 57,007 & 129.18 & 92.06 & 141,576 & 116.94 & 85.43 \\
\hline 2018 & 135,072 & 81.77 & 68.02 & 25,586 & 57.98 & 44.88 & 109,486 & 90.44 & 77.33 \\
\hline 2019 & 118,256 & 71.59 & 87.55 & 17,257 & 39.10 & 67.45 & 100,999 & 83.43 & 92.25 \\
\hline
\end{tabular}

Source: Authors' calculation based on data collected from the ISAA survey on selected family farms

Table 3 shows the total production of pepper during the analyzed period both for the Republic of Serbia and for the particular regions of Serbia North and Serbia South. The maximum production for the whole country was 227,645 tons in 2016, and the lowest production was in 2019 and amounted to 118,256 tons. Based on the calculated indicators of the base index, it can be concluded that the highest total production was achieved in 2016, when it was $37.80 \%$ higher than in 2015 . The growth of production in relation to the base year was achieved in 2017 , as well, when the production was $20.21 \%$ higher. In the next two years (2018 and 2019), there was a decline in total production. In 2018 the 
production decreased by $18.13 \%$, while in $2019,28.41 \%$ less pepper was produced than in 2015. This trend of decreasing production volume can be explained by a relatively short shelf life of the product (fresh vegetables). Storage and canning is also challenging, especially for small farmerspe who often do not have the capacity necessary for further processing and transport to remote markets (Zečević et al., 2019).

Looking at the regions of Serbia North and Serbia South separately, the trend of increasing production is similar; in 2016 the increase was about 40\%, while in 2017 there was a slightly larger increase in the region of Serbia North. In the next two years (2018 and 2019), there was a decrease in production, more pronounced in the region of Serbia North, where in 2018 production was $22.02 \%$ lower, and in 2019 it was $60.90 \%$ lower. The indicators obtained by calculating the chain indices show changes in the produced quantities when compared to the previous year. Based on these indicators, it can be concluded that, when compared to the previous year, the growth of production was recorded only in 2016 (37.80\% growth), while in the following years there was a decline, because the highest pepper production was achieved in 2016. Looking at the regions of Serbia North and Serbia South, the obtained indicators are similar to the ones for the entire country, with larger reductions from year to year in the region of Serbia North.

\section{Financial aspects of pepper production on farms in the Republic of Serbia}

Some authors suggest the use of different methodologies for the purpose of determining the efficiency of the resource used. This should help farmers to observe the degree of sustainability of their activity, save money and improve their competitiveness (Elzaki et al., 2019). As one of the indicators for the stated needs, it is possible to use the calculation of gross margin. Gross margin is determined as the difference between the selling price per unit of product and variable costs per unit of product and it is the first indicator of profit potential, i.e. it indicates the contribution of each unit of product to the covering of the fixed costs and obtaining the gross profit. The gross margin is also used to determine the break-even point, to optimize the product range, to decide on the introduction of new product or eliminate the existing products (Weygandt et al., 2018). In addition, the gross margin is used as the first indicator of business risk, which allows farmers to take appropriate actions to minimize the loss.

According to the FADN methodology, two approaches are possible when calculating the gross margin at the level of farm. The first combines the value of production and total variable costs, and according to the second one, gross margin is determined as the difference between the value of products sold externally and variable costs that lead to an outflow of funds (Ivanović et al., 2018). For the purposes of this paper, the gross margins was calculated according to the first approach.

Total variable costs in pepper production include costs arising from: land preparation, procurement of seeds and seedlings, weed control, fertilization, irrigation, pesticides and disease treatment, harvesting, salaries of permanent and seasonal labor force. In addition to the above, they also include components such as interest on working capital, crop insurance costs and others (Takele 2001; Gogić 2014). 
The average annual amounts of production value, variable costs and gross margin in the production of pepper on family farms in the Republic of Serbia were calculated on the basis of direct costing calculation (calculations based on variable costs) for the analyzed period 2015-2019. Variability of the stated financial indicators for the period 2015-2019 calculated per 1 hectare, is shown in Figure 1.

Figure 1. Variation of financial indicators for pepper production in the period 2015-2019 (calculation for 1 hectare)

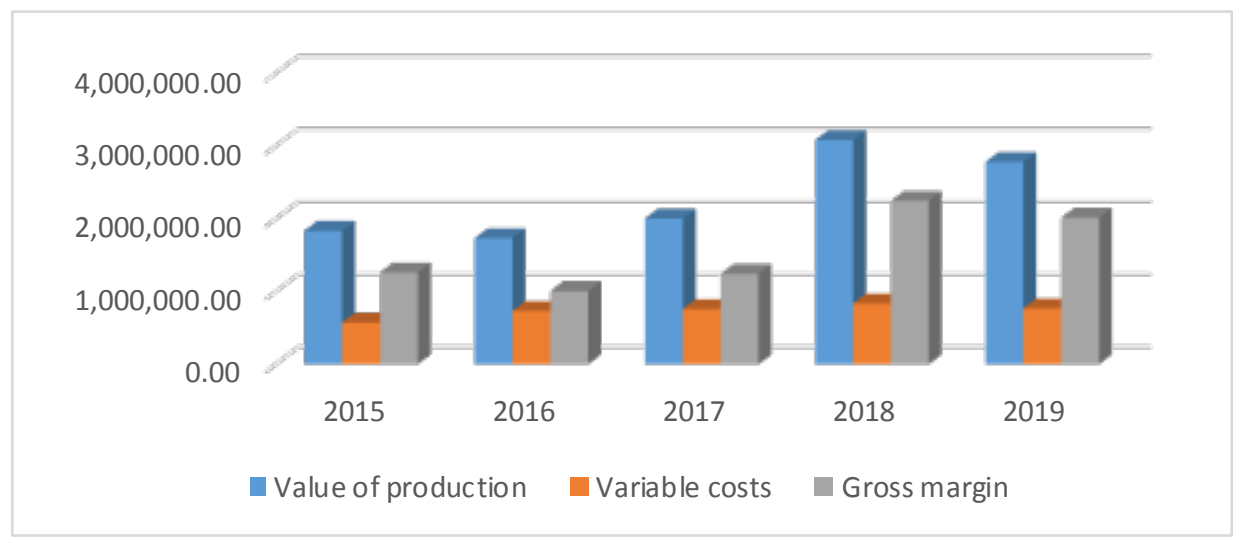

Source: Authors' calculation based on data collected from the ISAA survey on selected family farms Based on the Figure 1, it can be seen that the largest amounts of all financial indicators were recorded in 2018. The lowest production value and gross margin were recorded in 2016, while the lowest variable costs were recorded in 2015.

Table 4. Financial indicators of pepper production for the 2015-2019 period (calculation for 1 hectare)

\begin{tabular}{|c|c|c|c|c|c|}
\hline Year & 2015 & 2016 & 2017 & 2018 & 2019 \\
\hline Production value (RSD) & $1,833,560.00$ & $1,732,450.00$ & $2,000,702.70$ & $3,079,949.55$ & $2,779,809.41$ \\
\hline FBIN (\%) & 100.00 & 94.49 & 109.12 & 167.98 & 151.61 \\
\hline CBIN (\%) & 100.00 & 94.49 & 115.48 & 153.94 & 90.26 \\
\hline Variable costs (RSD) & $572,526.79$ & $729,869.32$ & $759,711.20$ & $835,756.77$ & $767,564.44$ \\
\hline FBIN (\%) & 100.00 & 127.48 & 132.69 & 145.98 & 134.07 \\
\hline CBIN (\%) & 100.00 & 127.48 & 104.09 & 110.01 & 91.84 \\
\hline Gross margin (RSD) & $1,261,033.21$ & $1,002,580.68$ & $1,240,991.50$ & $2,244,192.78$ & $2,012,244.97$ \\
\hline FBIN (\%) & 100.00 & 79.50 & 98.41 & 177.96 & 159.57 \\
\hline CBIN (\%) & 100.00 & 79.50 & 123.78 & 180.84 & 89.66 \\
\hline $\begin{array}{c}\text { Share of gross margin in } \\
\text { production value (\%) }\end{array}$ & 68.78 & 57.87 & 62.03 & 72.86 & 72.39 \\
\hline
\end{tabular}

Source: Authors' calculation based on data collected from the ISAA survey on selected family farms 
Table 4 shows the most significant financial indicators calculated based on variable costs in pepper production for the period 2015-2019 (calculated for 1 hectare). The value of pepper production in 2015 amounted to 1,833,560.00 dinars/ha, while in the following year it decreased, which is also the lowest amount in the analyzed period $(1,732,450.00$ dinars/ha). During the next three years, the value of production increased. In 2017, the value of production amounted to 2,000,702.70 dinars/ha, and in 2018, when the largest amount was recorded $(3,079,949.55$ dinars/ha). In 2019, there is a slight decrease in the amount of production value $(2,779,809.41$ dinars/ha).

Observing the indicators calculated on the basis of base indices, it can be concluded that only in 2016 there was a decrease of $5.51 \%$ in the value of pepper production, compared to the base year (2015), while in other analyzed years there was an increase. In 2017 , the increase in the value of production amounted to $9.12 \%$, and in 2018 as much as $67.98 \%$, compared to the base year. In the last analyzed year, the increase in the value of pepper production was $51.61 \%$, compared to the base year. Indicators obtained on the basis of chain indices show that in 2017, compared to 2016, there was an increase of $15.48 \%$ in the value of production. In 2018 , the value of production was $53.94 \%$ higher compared to 2017, while in 2019 the value of production decreased by $9.74 \%$, compared to 2018 .

Production costs are determined by the quality of the used inputs and their prices. The coefficient of cost-effectiveness (obtained as the ratio between the value of production and production costs) indicates the degree to which resources are rationally used (Pavlović et al., 2010). Variable costs in pepper production recorded a continuous growth in some of the analyzed years, except in 2019, when they were slightly lower compared to the previous year. In 2015, the lowest variable costs of pepper production were recorded, amounting to 572,526.79 dinars/ha, while the highest were in 2018, amounting to $835,756.77$ dinars/ha. The base and chain indices show that in 2016 the variable costs were $27.48 \%$ higher compared to the base year, while in 2017 there was an increase in variable costs compared to the base year by $32.69 \%$, and in comparison to the previous year by $4.09 \%$. In 2018 , when the variable costs were the highest, they increased by $45.98 \%$ compared to the base 2015 year, and compared to 2017 by $10.01 \%$. In 2019, variable costs were $34.07 \%$ higher compared to the base year, but there was a decrease in the amount of variable costs by $8.16 \%$ compared to 2018 .

The increase in the value of pepper production, which also affected the increase in the gross margin, was primarily due to the growth of market prices of pepper in 2018 and 2019, while the average yield of pepper was at a similar level as in the previous period. The growth of the market price was certainly significantly influenced by the reduction of areas on which pepper was grown in 2018 and 2019 (data shown in Table 2), which resulted in decline of total pepper production (data shown in Table 3). Since there was a smaller amount of pepper on the market compared to the previous period, this greatly influenced the increase in its market price. 
Due to the impact of variable costs on the amount of gross margin in pepper production, it is necessary to determine and analyze the structure of variable costs and see which costs have the largest share in this structure.

Figure 2. Structure of average variable costs in pepper production for the 2015-2019 period

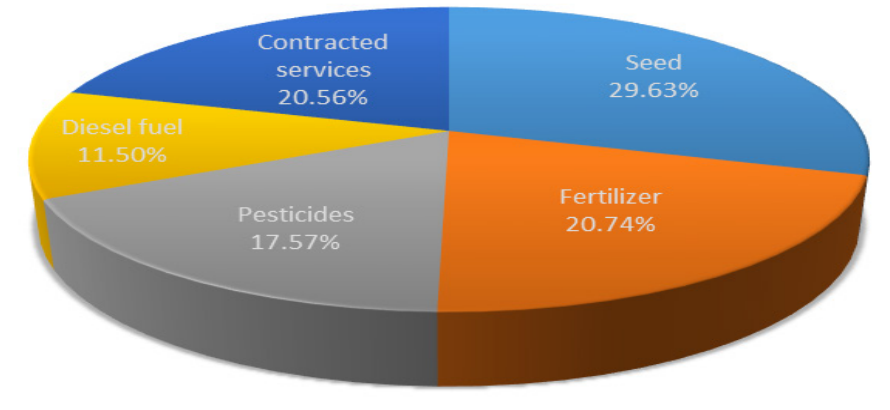

$\square$ Seed $\square$ Fertilizer $\square$ Pesticides $\square$ Diesel fuel $\square$ Contracted services

Source: Authors' calculation based on data collected from the ISAA survey on selected family farms

Based on the presented structure of average variable costs in pepper production (Table 2 ), it can be concluded that seed costs (29.63\%) and fertilizer costs (20.74) have a dominant share. The costs of contracted services have a slightly smaller share, which makes up $20.56 \%$ of the total variable costs in the production of pepper. They are followed by pesticide costs with $17.57 \%$ and diesel fuel costs with $11.50 \%$.

The gross margin in the production of pepper was highest in 2018, when it amounted to $2,244,192.78 \mathrm{dinars} / \mathrm{ha}$, while a slightly lower result was achieved in 2019. In other years, the gross margin was lower, while the lowest amount was recorded in 2016, when it amounted to 1,002,580.68 dinars/ha. The indicators obtained from the calculation of base indices show that the gross margin in pepper production varied over the years. In 2016, the gross margin was 20.50\% lower compared to the base year, while in 2017 it was slightly lower compared to 2015 (by 1.59\%). In the remaining two observed years, the gross margin of pepper was higher compared to the base year (2015), in 2018 by $77.96 \%$ and in 2019 by $59.57 \%$. The indicators obtained from the calculation of chain indices indicate variations in the amount of gross margins between the analyzed years. In 2016, the gross margin was 20.50\% lower compared to 2015, and in 2017 it was $23.78 \%$ higher compared to 2016 . In 2018, the growth trend of the gross margin continued and then there was an increase of $80.84 \%$ compared to the previous year. In 2019 , the gross margin decreased by $10.34 \%$ compared to the previous year.

The obtained financial indicators of pepper production on farms in the Republic of Serbia in the 2015-2019 period show that the largest share of gross margin in the value of production was in 2018 (when the largest amount of gross margin was recorded) and 
it amounted to $72.86 \%$. A similar result was recorded in 2019 , while in other years the share of gross margin in the value of production was somewhat lower, at the level of about $60 \%$.

There is an opinion that the gross margin is an important indicator that the company (farm) creates in relation to competitors (Engle, 2013). For the purposes of assessing economic efficiency, it is important to compare the gross margin with a similar farms, taking into account whether it is production in the open field or in greenhouses, or whether it is a conventional method of production, or it is an organic production (Lampkin et al., 2001).

The previous analysis indicates that the selling price of pepper had a dominant influence on the value of production, and thus on the amount of gross margin, and it ranged from 49.41 to 66.23 dinars $/ \mathrm{kg}$. The lowest price of pepper was recorded in 2017 , while the highest price was recorded in 2018. If we take into account the indicators that show significant changes in the value of production and gross margin between 2017 and 2018 , it can be concluded that the price had a great impact on the changes. In 2015 and 2016, the price of pepper was around 51 dinars $/ \mathrm{kg}$, and in 2019 it was 63.65 dinars $/ \mathrm{kg}$.

\section{Sensitivity analysis of gross margin in pepper production according to the changes in price and yield level}

Sensitivity analysis of gross margin in pepper production according to the changes in prices and yields for the 2015-2019 period on the basis of a five-year price average, yields and gross margins achieved on the surveyed farms is shown in Table 5.

Table 5. Sensitivity analysis of gross margin in pepper production according to changes in prices and yields

\begin{tabular}{|c|c|c|c|c|c|c|}
\hline \multirow{2}{*}{\multicolumn{2}{|c|}{ Yield (kg/ha) }} & \multicolumn{5}{|c|}{ Price (RSD/kg) } \\
\cline { 3 - 7 } & & $-20 \%$ & $-10 \%$ & Average & $+10 \%$ & $+20 \%$ \\
\cline { 3 - 7 } & 44.98 & $\mathbf{5 0 . 6 0}$ & $\mathbf{5 6 . 2 2}$ & 61.84 & $\mathbf{6 7 . 4 6}$ \\
\hline$-20 \%$ & $\mathbf{3 0 , 0 4 9 . 3 3}$ & $791,990,68$ & $960,928,00$ & $1,129,865.32$ & $1,298,802.65$ & $1,467,739.97$ \\
\hline$-10 \%$ & $33,805.49$ & $960,928,00$ & $1,150,982.49$ & $1,341,036.98$ & $1,531,091.46$ & $1,721,145.95$ \\
\hline Average & $\mathbf{3 7 , 5 6 1 . 6 6}$ & $1,129,865.32$ & $1,341,036.98$ & $\mathbf{1 , 5 5 2 , 2 0 8 . 6 3}$ & $1,763,380.28$ & $1,974,551.94$ \\
\hline$+10 \%$ & $41,317.83$ & $1,298,802.65$ & $1,531,091.46$ & $1,763,380.28$ & $1,995,669.10$ & $2,227,957.92$ \\
\hline$+20 \%$ & $45,073.99$ & $1,467,739.97$ & $1,721,145.95$ & $1,974,551.94$ & $2,227,957.92$ & $2,481,363.90$ \\
\hline
\end{tabular}

Source: Authors' calculation based on data collected from the ISAA survey on selected family farms

Based on the collected survey data on gross margins on farms where pepper is the dominant crop in the period 2015-2019, the average price, average yield and average gross margin in pepper production were calculated. The average price of pepper for the mentioned five-year period was 56.22 dinars $/ \mathrm{kg}$, the average yield was $37,561.66$ 
$\mathrm{kg} / \mathrm{ha}$, while the average gross margin was 1,552,208.63 dinars/ha. Based on the sensitivity analysis of the gross margin in pepper production, it can be concluded that when reducing the price and yield of peppers by $20 \%$, the amount of gross margin in pepper production is reduced by about $50 \%$, while increasing the price and yield by $20 \%$ would lead to an increase in gross margin by almost $60 \%$. Changes in the price and yield of peppers have the significant impact on the amount of gross margin in pepper production.

It is interesting to note that the price of pepper has significant oscillations in the past 15 years and that the price ranged from $188.3 \mathrm{EUR} / \mathrm{t}$ (2006) to $447.8 \mathrm{EUR} / \mathrm{t}$ (2017). Based on the model used by a group of authors (Mihajlović et al., 2019) for the purpose of forecasting the price of pepper for the period of five years (2018-2022) it is expected that the selling price of pepper will continue to grow and in 2022 it will amount to $530.8 \mathrm{EUR} / \mathrm{t}$. This is important information for business planning purposes in the coming period. Additionally, the price of pepper varies between seasons, as well as between years. Seasonal variations can be explained by the influence of weather conditions, the occurrence of diseases and pests, while variations in prices between years can be explained by variations in areas sown and yields obtained, as well as due to climatic factors (Kelley and Boyhan, 2009). Starting from the stated point of view, the profitability of pepper production is determined by the quality and quantity of pepper produced, as well as their selling prices (Russo \& Vincent, 2012).

\section{Sensitivity analysis of gross margin in pepper production according to the changes in the amount of variable costs}

Table 6 shows the analysis of the gross margin sensitivity in pepper production according to changes in costs that have the largest share in the structure of variable costs. Based on the collected data, it was determined that the share of seed costs makes up around $29.63 \%$, while fertilizer costs make up $20.74 \%$ of the total variable costs. In third place according there are the costs of contracted services, which participate by $20.56 \%$.

Table 6. Sensitivity analysis of gross margin in pepper production according to the changes in seed and fertilizer costs

\begin{tabular}{|c|c|c|c|c|c|c|}
\hline \multirow{2}{*}{$\begin{array}{l}\text { Fertilizer costs (RSD/ } \\
\text { ha) }\end{array}$} & \multicolumn{5}{|c|}{ Seed costs (RSD/ha) } \\
\cline { 3 - 7 } & $-20 \%$ & $-10 \%$ & Average & $+10 \%$ & $+20 \%$ \\
\cline { 3 - 7 } & $\mathbf{1 7 1 , 0 5 6 . 3 9}$ & $\mathbf{1 9 2 , 4 3 8 . 4 4}$ & $\mathbf{2 1 3 , 8 2 0 . 4 9}$ & $\mathbf{2 3 5 , 2 0 2 . 5 4}$ & $\mathbf{2 5 6 , 5 8 4 . 5 9}$ \\
\hline$-20 \%$ & $\mathbf{1 1 9 , 7 5 9 . 2 8}$ & $1,624,912.55$ & $1,603,530.50$ & $1,582,148.45$ & $1,560,766.40$ & $1,539,384.35$ \\
\hline$-10 \%$ & $\mathbf{1 3 4 , 7 2 9 . 1 9}$ & $1,609,942.64$ & $1,588,560.59$ & $1,567,178.54$ & $1,545,796.49$ & $1,524,414.44$ \\
\hline Average & $\mathbf{1 4 9 , 6 9 9 . 1 0}$ & $1,594,972.73$ & $1,573,590.68$ & $\mathbf{1 , 5 5 2 , 2 0 8 . 6 3}$ & $1,530,826.58$ & $1,509,444.53$ \\
\hline$+10 \%$ & $\mathbf{1 6 4 , 6 6 9 . 0 1}$ & $1,580,002.82$ & $1,558,620.77$ & $1,537,238.72$ & $1,515,856.67$ & $1,494,474.62$ \\
\hline$+20 \%$ & $\mathbf{1 7 9 , 6 3 8 . 9 2}$ & $1,565,032.91$ & $1,543,650.86$ & $1,522,268.81$ & $1,500,886.76$ & $1,479,504.71$ \\
\hline
\end{tabular}

Source: Authors' calculation based on data collected from the ISAA survey on selected family farms 
Based on the collected survey data of gross margins on farms where pepper is the dominant crop in the 2015-2019 period, the average variable costs were calculated. The largest share in the variable costs' structure have the costs of seeds and fertilizer. Average costs of pepper seeds for the analyzed 2015-2019 period amounted to 213,820.49 dinars/ ha, while the average costs of fertilizers amounted to $149,699.10$ dinars/ha. When the costs of seeds and fertilizers are reduced or increased by $20 \%$, the gross margin in the production of pepper increases or decreases by about $5 \%$. Based on the analysis, it can be concluded that the changes in the amount of costs that have the largest share in the structure of variable costs (in this case the costs of seeds and fertilizers), do not have a significant impact on changes in gross margin in pepper production.

\section{Economic sustainability of pepper production in the Republic of Serbia}

Competitiveness can be viewed from at least two points of view: how successful the entity is in relation to other farmers (expressed through profitability, market share) and secondly the ability to offer products of appropriate quality at a lower price, or higher quality at the same selling price as competitors, which assumes lower production costs, the application of modern technology and higher productivity (Ion et al., 2019).

Having in mind the fact that family farms appear as the key actors of agricultural production in the Republic of Serbia, the question of their competitiveness can be quite justifiably raised. Namely, the average age of household members is extremely unfavorable in order to cope with the challenges that the wave of changes at the global level brings. The key challenges are reflected not only in intensive climate changes, which undoubtedly affect the quality and quantity of pepper production, especially due to the fact that in Serbia it is mostly carried out outdoors, but also due to unfavorable economic trends, regulatory changes, globalization of supply chain operations, changes in quality standards and the emergence of modern technology (Bodiroga et al., 2018). Additionally, the technology of production, processing and sale of agricultural products has changed (Repar et al, 2018). In modern business conditions, entire supply chains compete with each other (Savić et al., 2016). A horizontal link in the supply chain means that small farmers can work with commercial pepper producers. Vertical connectivity implies that different participants cooperate with each other, thus providing a benefit in the form of skills transfer from one participant to another, which consequently reduces transaction costs (Makoka et al., 2010). Relationships and conflict avoidance relationships can contribute to maintaining and improving product quality, increasing sales volume and reducing production costs, while maintaining market share (Belaya et al., 2016). However, for economic success, it is not enough just to produce a quantity of products of a certain quality, but the conditions under which the placement of these products is carried out are also of key importance. Research shows that reducing the costs of sales in the agricultural sector is closely related to an increase of productivity (Staboulis et al., 2019).

Although the projections indicate that a growing trend in the selling price of pepper can be expected in the upcoming period, the experiences so far remind us that surprises are quite possible. In addition, the question is open how much farmers benefit from high market 
prices in retail and whether they will be ready to continue with the given production in the future due to all the described risks? Due to the pronounced volatility of sales prices, one of the ways to protect farmers from price risks is contracting (contract farming), i.e. concluding contracts with customers, which will specify the quantity, quality and selling price of the product. The results of previous research indicate that in this way it is possible to ensure vertical integration in the supply chain and at the same time to reduce transaction costs and strengthen the economic status of farmers (Harish 2019).

\section{Conclusion}

The paper discusses the trends of areas sown under pepper on the territory of the Republic of Serbia with the aim of assessing the sustainability of this production through the prism of economic indicators, given its significant contribution to exports and total GDP. The observed negative tendencies, such as the pronounced oscillation of production costs and sales prices, significantly complicate the production planning and open a number of existential issues that farmers face with.

The fact that farmers represent one of the segments in the agri-food supply chain, provides them with the opportunity to improve their position through cooperative relations with other participants. In reality, it is not uncommon for production costs and product sales prices to move in the opposite direction, which affects negatively gross margin as one of the key indicators of value creation. Protection against price risk can be achieved by negotiating the prices at which the farmers will deliver their products. Namely, the sensitivity analysis conducted in the paper indicates that in the case of a decrease in prices and yields (production value) by $20 \%$, the gross margin decreases by about $50 \%$. Contracted farming is one of the options that can reduce price risk on the sales side and can contribute to the improvement of the profitability for farmers, and thus the sustainability of this production.

\section{Acknowledgements}

The paper is a result of the researches No. 451-03-9/2021-14/ 200045 and No. 45103-1/2021-16/35, financed by the Ministry of Education, Science and Technological Development of the Republic of Serbia.

\section{Conflict of interests}

The authors declare no conflict of interest.

\section{References}

1. Belaya, V., \& Hanf, J. H. (2016). Conflict Resolution in Vertical Collaborations in the Agrifood Sector, International Journal on Food System Dynamics, 7(1), 24-35.

2. Bodiroga, R., Sredojević, Z., \& Subić, J. (2018). Economic efficiency of investment in greenhouse vegetable production without heating, Economics of Agriculture, 65(4), 1383-1393. 
3. Elzaki Ali, R., Saied; M., \& Elsebaei, M. (2019). Vegetable production in Saudi Arabia: Protection coefficient and relative efficiency, Economics of Agriculture, 66(2), 457-469. DOI: 10.5937/ekoPolj1902457E.

4. Engle, P. (2013). Understanding gross margin, Industrial Engineer, 45(4), 20-20.

5. Gachukia, M. (2016). Value Chain Governance and Governmentality of Horticultural Exporters by Developing Economies: A perspective of Kenya's Fresh Fruit and Vegetable Export Sector, International Journal on Food System Dynamics, 7(1), 14-23.

6. Gogić, P. (2014). Theory of costs with calculations in production and processing of agricultural products, Poljoprivredni fakultet, Beograd. [In Serbian: Гогић, П. (2014). Теорија трошкова са калкулацијама у производњи и преради пољопривредних производа].

7. Harish, N. (2019). Impact of contract farming on economic status of the farmers practicing contract farming, International Journal of Arts, Science and Humanities, $7(2), 39-46$.

8. Institute for Science Application in Agriculture, Survey of gross margin on selected family farms in the Republic of Serbia [In Serbian: Институт за примену науке у пољопривреди, Анкета покрића варијабилних трошкова на одабраним пољопривредним газдинствима у Републици Србији].

9. Ion, R., Dobre, I., \& Saproni, V. (2019). Efficiency versus competitiveness in Romanian agriculture: Case study, Institute of Agricultural Economics, Belgrade, 66(3), 691-705.

10. Ivanović, S., Vasiljević, Z., \& Todorović, S. (2018). The gross margin calculating according FADN methodology in crop production, In: Conference of agronomists and farmers of Serbia, Agriculture faculty, Belgrade, [In Serbian: Ивановић, С., Васиљевић, 3., \& Тодоровић, С. (2018). Утврђивање бруто марже по FADN методологији у ратарској производњи, Саветовање агронома и пољопривредника Србије, 17. април 2018, 81-87, Пољопривредни факултет, Београд].

11. Kelley, T., \& Boyhan, G. (2009). Commercial Pepper Production Handbook, The University of Georgia, Colleges of Agricultural and Environmental Sciences \& Family and Consumer Sciences.

12. Lampkin, N., \& Measures, M. (2001). Organic Farm Management Handbook, Organic Farming Research Unit, Institute of Rural Studies, University of Wales. Organic Advisory Service, Elm Farm Research Centre, Aberystwyth, Newbury.

13. Makoka, D., Chitika, R., \& Simtowe, F. (2010). Value chain analysis of Pepper and Bird's Eye Chillies in Malawi. University of Malawi, Centre for Agricultural Research and Development, Retrieved from https://mpra.ub.uni-muenchen.de/id/ eprint/27785 (December 4, 2020).

14. Maksimović, P. (2004). Pepper Production, Pantenon, Beograd. [In Serbian: Максимовић, П. (2014). Производња паприке]. 
15. Mihajlović, Š., Vukelić, N., Novković, N., \& Mutavdžić, B. (2019). Vegetable prices in Serbia - tendencies and forecasting, Economics of Agriculture, 66(2), 485-498.

16. Pavlović, N., Ugrinović, M., \& Zdravković, M. (2010). Economic and agronomic analysis of organic production of tomato and pepper. Economics of agriculture, 57(Spec. num. 2), 153-157.

17. Peševski, M., Tomić, D., Rajić, Z., Živković, D., \& Mićić, I. (2016). The impact of income from the plastic tunnel production of tomatoes, peppers and cucumbers over the family budget of the selected agricultural households, In: 2nd international symposium for agriculture and food, ISAF 2015, 7-9. October 2015, 269-275, Faculty of Agricultural Sciences and Food of Ss. „Cyril and Methodius“ University in Skopje, Republic of Macedonia.

18. Repar, A., L., Onakuse, S., Bogue, J., \& Afonso, A., (2018). Is It All About the Money? Extent, Reasons and Triggers for Side-selling in Malawi's Pepper Supply Chain, International Journal on Food System Dynamics, 9(1), 38-53. DOI:http:// dx.doi.org/10.18461/ijfsd.v9i1.913

19. Russo, I., \& Vincent, M. (2012). Peppers: Botany, production and uses, CPI Group, Ltd, Croydon.

20. Savić, B., Vasiljević, Z., \& Popović, N. (2016). The role and importance of strategic budgeting for competitiveness of the agribusiness supply chain. Economics of Agriculture, 63(1), 295-312.

21. Seepersad, G., Iton, A., Paul, C., \& Lawrence, J. (2013). Financial Aspects of Greenhouse Vegetables Production Systems in Jamaica and Trinidad \& Tobago, Retrieved from http://www.cardi.org/wp-content/uploads/downloads/2018/03/ Publ-20-Financial-Aspects-Greenhouses-Govind-S.pdf (December 6, 2020).

22. Staboulis, C., Natos, D., \& Mattas, K. (2019) Estimating the impact of trade costs on agricultural productivity, International Journal on Food System Dynamics, 10(3), 278-286.

23. Statistical Office of the Republic of Serbia (2012). Agriculture in Republic of Serbia, Agriculture Census, Book 1, Belgrade. [In Serbian: Републички завод за статистику (2012). Пољопривреда у Републици Србији, Попис пољопривреде, Књига 1, Београд].

24. Takele, E., (2001). Bell pepper production, Sample Costs and Profitability Analysis, University of California, Agriculture and Natural Resources, Oakland.

25. Weygandt, J., Kimmel, P., \& Kieso, D. (2018). Managerial Accounting Tools for Business Decision Making, John Wiley \& Sons Inc., Hoboken.

26. Zečević, M., Pezo, L., Bodroža-Solarov, M., Brlek, T., Krulj, J., Kojić, J., \& Marić, B. (2019). A Business model in agricultural production in Serbia, developing towards sustainability, Economics of Agriculture, 66(2), 437-456. 